\title{
COVID-19 in the Indigenous Population of Brazil
}

\author{
Camila Vantini Capasso Palamim ${ }^{1,2}$ (1) $\cdot$ Manoela Marques Ortega ${ }^{1,2}$ (D) $\cdot$ Fernando Augusto Lima Marson ${ }^{1,2}$ (i)
}

Received: 16 June 2020 / Revised: 22 September 2020 / Accepted: 28 September 2020 / Published online: 6 October 2020

(C) W. Montague Cobb-NMA Health Institute 2020

\begin{abstract}
Brazil has 896,917 Indigenous individuals distributed among 505 Indigenous lands. There are 274 different Indigenous languages within 305 Indigenous ethnic groups. The Indigenous population is susceptible to pandemics, especially to the current pandemic of COVID-19, which has spread rapidly. In Brazil, after the first COVID-19-confirmed Indigenous case on 05th June 2020, more 420 suspected cases, 1727 confirmed cases being 934 active cases, 715 cases with clinical cure, and 70 cases of death were accounted through the first week of June. The number of cases is underestimated, according to the Special Secretariat for Indigenous Health (SESAI) database, since the deaths are due to respiratory failure, possibly caused by COVID-19, but not confirmed. The first COVID-19-caused death was a 15-year-old Indigenous Yanomami teenage from Roraima State without known previous diseases history and/or comorbidities. In the present study, the importance of social isolation, especially for Indigenous people who are more vulnerable to the COVID-19, was highlighted by the identification of the infection community. An Indigenous of the Kokama ethnicity was infected after coming in contact with a Medical Doctor who was infected with the disease. Later, it was noticed that both, Indigenous and doctor, were responsible for COVID-19's transmission to 43 other Indigenous individuals (30 in Alto Rio Solimões and 13 in Parintis), causing possibly other confirmed deaths. The impact of COVID-19 for Indigenous population might be an unprecedented tragedy, and the government in Brazil must take emergency measures as the social isolation.
\end{abstract}

Keywords Brazil · Coronavirus · Indigenous · Social science $\cdot$ Indigenous population $\cdot$ SARS-CoV-2 $\cdot$ COVID-19 $\cdot$ Health care

\section{Introduction}

Coronavirus disease 2019 (COVID-19) is an infectious disease caused by severe acute respiratory syndrome coronavirus 2 (SARS-CoV-2) that was first identified in December 2019 in Wuhan, China, and it has spread globally causing a pandemic.

Fernando Augusto Lima Marson

fernandolimamarson@hotmail.com; fernando.marson@usf.edu.br

Camila Vantini Capasso Palamim

cvcpalamim@gmail.com

Manoela Marques Ortega

manoela.ortega@usf.edu.br

1 Laboratory of Cell and Molecular Tumor Biology and Bioactive Compounds, São Francisco University, Avenida São Francisco de Assis, 218. Jardim São José, Bragança Paulista 12916-000, São Paulo, Brazil

2 Laboratory of Human and Medical Genetics, São Francisco University, Avenida São Francisco de Assis, 218. Jardim São José, Bragança Paulista, São Paulo 12916-900, Brazil
According to the World Health Organization (WHO), in 05th June 2020, more than 6.8 million cases have been reported across 213 countries and 2 international conveyances and more than $\sim 400,000$ deaths reported [1, 2]. In Brazil, a total of 630,708 cases with 34,625 deaths were described, which occurred in all Brazilian states and Federal District.

The COVID-19 pandemic started at a time when Brazilian government is seeking to develop the Amazon for mining, logging, farming, and reviewing the protected status of the tribal lands. At the same time, malnutrition, hepatitis B, tuberculosis, and diabetes as well as the lack of access to health care could mean that these tribes would be particularly vulnerable to the virus outbreak. Indigenous groups are urging intruders, miners, loggers, poachers, drug traffickers, land grabbers, missionaries, and tourists who can be vectors of transmission to expel from their lands outsiders who could introduce the disease, according to the Indigenous Organizations of the Brazilian Amazon.

Indigenous tribes have already seen their communities ravaged by exogenous diseases in the past. During the 2009 H1N1 influenza pandemic, their death rate was 4.5 times higher than the rest of the Brazil's general population [3]. 
Moreover, vaccination as management against $\mathrm{H} 1 \mathrm{~N} 1$ failed to protect an Indigenous community in 2016, and hundreds of Indians, mainly from Guaraní tribe in the south of Brazil, have died [4]. Presently, respiratory diseases cause approximately one-third of Indigenous deaths in Brazil, which can be a complicating factor during the COVID-19 pandemic.

To safeguard the vulnerable Indigenous from Brazil, the COVID-19 data needs to be disaggregated by ethnicity, since the sequence of SARS-CoV-2 analysis has showed that the genome sequences of the virus from different patients are very conserved [5]. Thus, the aim of the present study is to discuss the epidemiologic and social characteristics of indigenous population aiming to protect them from COVID-19 pandemic.

\section{Perspective}

In 2010, the Brazilian Institute of Geography and Statistics (IBGE) has conducted the last population census in Brazil [6]. In this context, some peculiarities in relation to the Indigenous population who live in Brazil and the possible devastating effects of COVID-19 on this population are described in the present study. The Indigenous population has been reported in all Brazilian states and Federal District. Thus, 896,917 (517,383 in Indigenous lands and 379,534 in urban areas) Indigenous individuals were censured in 2010, in accordance with their traditions, customs, culture, and ancestry. In addition, 505 Indigenous lands and territories were described, representing $\sim 12.5 \%$ of the Brazilian territory, which there was a wide variation in the number of Indigenous inhabitants per land $[6,7]$. Thus, six lands presented more than 10,000 Indians, 107 presented between more than 1000 and less than 10,000 Indians, 291 between more than 100 and less than 1000 Indians, and 83 up to 100 Indians. The land with the largest indigenous population was Yanomami in the Amazonas and Roraima States with 25,700 Indigenous individuals. In brief, Table 1 shows the number of inhabitants, number of Indigenous individuals by living at indigenous lands or in urban areas, demographic density, and area distributed by Brazilian states and Federal District.

Despite the identical gender ratio inside all Indigenous population $(\sim 50 \%)$, Indian females are more prevalent in urban areas and Indian males in Indigenous lands. In the Indigenous population, high fertility and mortality rates have been described, which characterizes an age pyramid with a broad base. The Indigenous population is currently divided into 305 ethnic groups according to linguistic, cultural, and social affinities (250 on Indigenous lands and 300 outside their lands), being the largest one known as Tikúna (6.8\% of the indigenous population). The ethnicities' concentration in Indigenous lands occur from 251 to 500 individuals by community, contrasting with outside Indigenous lands that occur from 50 to 10,000 individuals. In relation to cultural diversity, an important marker is the language, which totalizing 274 different ones. The percentage of Indigenous population who speak Portuguese, the national language of Brazil, is extremely variable between ethnic groups.

Interestingly, $12.6 \%$ of the indigenous' homes are known as hollow type called as "Oca or maloca," while the rest as "house" type, predominately. In Indigenous lands, "Ocas" type is also not common, only $2.9 \%$ contrasting with $58.7 \%$ of "house" type. In addition, $36.1 \%$ of Indigenous' homes have no bathroom, and in Indigenous lands, there are highest sewage deficits with a predominance of the use of the rudimentary cesspool $(65.7 \%)$. Moreover, access to water supply, electricity, and garbage collection was more precarious for individuals living on Indigenous lands than in urban areas.

Among the Indigenous population, 52.9\% has no income whatsoever and it is observing a greater proportion in Indigenous lands $(65.7 \%)$ compared with urban areas. It is possible also to verify that many jobs are carried out collectively according to their culture. In the Indigenous population structure, recreation and work are not easily separable and the relationship with the land is wide broad, not having an association with private property.

In Brazil, the Indigenous community fears the COVID-19 pandemic [8], and although containment measures have been taken, it was not possible to prevent the contagion of the Indigenous population. Currently, according to the Ministry of Health by the Special Secretariat for Indigenous Health [9] (05th June 2020), among the Indigenous population are as follows: (i) 420 suspected cases; (ii) 1737 confirmed cases being 934 active cases; (iii) 715 recovered cases; (iv) and 70 deaths (Table 2). The deaths occurred in 18 special Indigenous health district (dSEI) from a total of 34 dSEIs, mainly affecting Alto do Rio Solimões (23 deaths), Guamá-Tocantins (11 cases), and Alto Rio Negro (5 cases). Possibly, the data presented does not represent the total number of cases, and it is not updated daily [10]. As historical marks for COVID-19 in Brazil and its prevalence in the Indigenous population, we have:

(i) 4th April 2020: first Indigenous COVID-19 positive from Yanomami ethnicity in the dSEI Yanomami was reported. The Indigenous case was of 15-year-old teenager admitted to the General Hospital of Roraima. After admission, the patient's condition worsened and needs to be transferred to an intensive care unit.

(ii) 8th April 2020 (date of the bulletin): An Indigenous Kokama ethnicity, 20 years old, tested COVID-19 positive in the dSEI Alto Rio Solimões - Amazonas. The Indigenous woman had contact with a Medical Doctor who just had returned from vacation (his COVID-19 positive test results comes out on 25th March 2020). The doctor has consulted ten patients before the COVID-10 diagnosis. 
Table 1 Description of the number of inhabitants in Brazil, demographic density, number of cases and deaths by COVID-19 at 03rd May 2020, number of beds in the intensive care unit (ICU, according to the Federal Council of Medicine in 2019), and description of the indigenous population

\begin{tabular}{|c|c|c|c|c|c|c|c|c|c|c|c|}
\hline \multirow{2}{*}{$\begin{array}{l}\text { States and } \\
\text { Federal } \\
\text { District }\end{array}$} & \multirow{2}{*}{$\begin{array}{l}\text { Area } \\
\left(\mathrm{km}^{2}\right)\end{array}$} & \multirow[t]{2}{*}{ Inhabitants } & \multirow{2}{*}{$\begin{array}{l}\text { Demographic } \\
\text { density }\end{array}$} & \multirow{2}{*}{$\begin{array}{l}\text { Cases of } \\
\text { COVID- } \\
19\end{array}$} & \multirow{2}{*}{ Deaths } & \multirow{2}{*}{$\begin{array}{l}\text { Number } \\
\text { of beds in } \\
\text { the } \\
\text { intensive } \\
\text { care unit }\end{array}$} & \multirow{2}{*}{$\begin{array}{l}\text { Number of } \\
\text { beds in the } \\
\text { intensive } \\
\text { care unit } \\
\text { by } 10,000 \\
\text { inhabitants }\end{array}$} & \multicolumn{4}{|c|}{ Indigenous population } \\
\hline & & & & & & & & $\begin{array}{l}\text { Indigenous } \\
\text { population } \\
\text { (total) }\end{array}$ & $\begin{array}{l}\text { Living at } \\
\text { Indigenous } \\
\text { lands }\end{array}$ & $\begin{array}{l}\text { Living } \\
\text { at } \\
\text { outside } \\
\text { their } \\
\text { lands }\end{array}$ & $\begin{array}{l}\% \text { of } \\
\text { Indigenous } \\
\text { living at } \\
\text { Indigenous } \\
\text { lands }\end{array}$ \\
\hline Brazil & $8,515,767$ & $190,732,694$ & 22.43 & 96,559 & 6750 & - & - & 896,917 & 517,383 & 379,534 & 57.7 \\
\hline North region & $3,853,677$ & $15,865,678$ & 4.12 & 12,774 & 872 & - & 0 & 342,836 & 251,891 & 90,945 & 73.5 \\
\hline Rondônia & 237,591 & $1,560,501$ & 6.58 & 653 & 23 & 294 & 1.63 & 13,076 & 9217 & 3859 & 70.5 \\
\hline Acre & 164,123 & 732,793 & 4.47 & 553 & 22 & 75 & 0.9 & 17,578 & 13,308 & 4270 & 75.7 \\
\hline Amazonas & $1,559,159$ & $3,480,937$ & 2.23 & 6062 & 501 & 502 & 1.24 & 183,514 & 129,529 & 53,985 & 70.6 \\
\hline Roraima & 224,301 & 451,227 & 2.01 & 668 & 9 & 48 & 0.92 & 55,922 & 46,505 & 9417 & 83.2 \\
\hline Pará & $1,247,955$ & $7,588,078$ & 6.07 & 3460 & 273 & 984 & 1.18 & 51,217 & 35,816 & 15,401 & 69.9 \\
\hline Amapá & 142,829 & 668,689 & 4.69 & 1187 & 40 & 82 & 1.03 & 7411 & 5956 & 1455 & 80.4 \\
\hline Tocantins & 277,721 & $1,383,453$ & 4.98 & 191 & 4 & 221 & 1.43 & 14,118 & 11,560 & 2558 & 81.9 \\
\hline $\begin{array}{l}\text { Northeast } \\
\text { region }\end{array}$ & $1,554,292$ & $53,078,137$ & 34.15 & 28,612 & 1844 & & & 232,739 & 106,142 & 126,597 & 45.6 \\
\hline Maranhão & 331,937 & $6,569,683$ & 19.81 & 3805 & 224 & 787 & 1.12 & 38,831 & 29,621 & 9210 & 76.3 \\
\hline Piauí & 251,578 & $3,119,015$ & 12.40 & 665 & 26 & 351 & 1.1 & 2944 & - & 2944 & - \\
\hline Ceará & 148,920 & $8,448,055$ & 56.76 & 8309 & 638 & 1201 & 1.33 & 20,697 & 2988 & 17,709 & 14.4 \\
\hline $\begin{array}{l}\text { Rio Grande } \\
\text { do Norte }\end{array}$ & 52,811 & $3,168,133$ & 59.99 & 1366 & 59 & 601 & 1.71 & 2597 & - & 2597 & - \\
\hline Paraíba & 56,585 & $3,766,834$ & 66.70 & 1034 & 74 & 608 & 1.51 & 25,043 & 18,296 & 6747 & 73.1 \\
\hline Pernambuco & 98,312 & $8,796,032$ & 89.63 & 8145 & 628 & 1861 & 1.96 & 60,995 & 31,836 & 29,159 & 52.2 \\
\hline Alagoas & 27,779 & $3,120,922$ & 112.33 & 1372 & 58 & 491 & 1.45 & 16,291 & 6268 & 10,023 & 38.5 \\
\hline Sergipe & 21,915 & $2,068,031$ & 94.35 & 601 & 14 & 339 & 1.48 & 5221 & 316 & 4905 & 6.1 \\
\hline Bahia & 564,733 & $14,021,432$ & 24.82 & 3315 & 123 & 2029 & 1.32 & 60,120 & 16,817 & 43,303 & 28 \\
\hline $\begin{array}{l}\text { Southeast } \\
\text { region }\end{array}$ & 924,621 & $80,353,724$ & 86.92 & 46,728 & 3748 & & & 99,137 & 15,904 & 83,233 & 16 \\
\hline $\begin{array}{l}\text { Minas } \\
\text { Gerais }\end{array}$ & 586,522 & $19,595,309$ & 33.41 & 2023 & 88 & 4341 & 2.06 & 31,677 & 9682 & 21,995 & 30.6 \\
\hline $\begin{array}{c}\text { Espírito } \\
\text { Santo }\end{array}$ & 46,096 & $3,512,672$ & 76.25 & 2985 & 103 & 1091 & 2.72 & 9585 & 3005 & 6580 & 31.4 \\
\hline $\begin{array}{l}\text { Rio de } \\
\text { Janeiro }\end{array}$ & 43,780 & $15,993,583$ & 365.23 & 10,546 & 971 & 6341 & 3.79 & 15,894 & 450 & 15,444 & 2.8 \\
\hline São Paulo & 248,222 & $41,252,160$ & 166.25 & 31,174 & 2586 & 11,863 & 2.63 & 41,981 & 2767 & 39,214 & 6.6 \\
\hline South region & 576,774 & $27,384,815$ & 48.58 & 5457 & 204 & & & 78,773 & 39,427 & 39,346 & 50.1 \\
\hline Paraná & 199,308 & $10,439,601$ & 52.40 & 1492 & 90 & 2858 & 2.52 & 26,559 & 11,934 & 14,625 & 44.9 \\
\hline $\begin{array}{l}\text { Santa } \\
\text { Catarina }\end{array}$ & 95,736 & $6,249,682$ & 65.29 & 2346 & 52 & 1108 & 1.58 & 18,213 & 9227 & 8986 & 50.7 \\
\hline $\begin{array}{l}\text { Rio Grande } \\
\text { do Sul }\end{array}$ & 281,730 & $10,695,532$ & 39.79 & 1619 & 62 & 2374 & 2.1 & 34,001 & 18,266 & 15,735 & 53.7 \\
\hline $\begin{array}{l}\text { Midwest } \\
\text { region }\end{array}$ & $1,606,404$ & $14,050,340$ & 8.75 & 2988 & 82 & & & 143,432 & 104,019 & 39,413 & 72.5 \\
\hline $\begin{array}{l}\text { Mato } \\
\text { Grosso do } \\
\text { Sul }\end{array}$ & 357,146 & $2,449,341$ & 6.86 & 266 & 9 & 484 & 1.78 & 77,025 & 61,158 & 15,867 & 79.4 \\
\hline $\begin{array}{l}\text { Mato } \\
\text { Grosso }\end{array}$ & 903,366 & $3,033,991$ & 3.36 & 331 & 12 & 877 & 2.62 & 51,696 & 42,525 & 9171 & 82.3 \\
\hline Goiás & 340,112 & $6,004,045$ & 17.65 & 825 & 30 & 1409 & 2.08 & 8583 & 336 & 8247 & 3.9 \\
\hline $\begin{array}{l}\text { Distrito } \\
\text { Federal }\end{array}$ & 5780 & $2,562,963$ & 444.07 & 1566 & 31 & 1031 & 3.39 & 6128 & - & 6128 & - \\
\hline
\end{tabular}


Table 2 Distribution of Indigenous affected by COVID19 for suspected cases, confirmed cases, recovered cases, and deaths distributed by the special indigenous health district (dSEI)

\begin{tabular}{|c|c|c|c|c|c|}
\hline dSEI & $\begin{array}{l}\text { Suspected } \\
\text { cases }\end{array}$ & $\begin{array}{l}\text { Confirmed } \\
\text { cases }\end{array}$ & $\begin{array}{l}\text { Active } \\
\text { cases }\end{array}$ & $\begin{array}{l}\text { Clinical cure } \\
\text { (recovered } \\
\text { cases) }\end{array}$ & Deaths \\
\hline Alagoas and Sergipe & 7 & 7 & 4 & 1 & 1 \\
\hline Altamira & 4 & 13 & 9 & 4 & 0 \\
\hline Alto Rio Juruá & 0 & 5 & 5 & 0 & 0 \\
\hline Alto Rio Negro & 0 & 113 & 99 & 9 & 5 \\
\hline Alto Rio Purus & 0 & 20 & 14 & 4 & 2 \\
\hline Alto Rio Solimões & 12 & 400 & 103 & 273 & 23 \\
\hline Amapá and Norte do Pará & 0 & 117 & 67 & 49 & 0 \\
\hline Araguaia & 0 & 0 & 0 & 0 & 0 \\
\hline Bahia & 4 & 11 & 10 & 0 & 0 \\
\hline Ceará & 69 & 143 & 95 & 45 & 2 \\
\hline Cuiabá & 0 & 0 & 0 & 0 & 0 \\
\hline Guamá-Tocantins & 3 & 137 & 76 & 50 & 11 \\
\hline Interior Sul & 39 & 87 & 47 & 40 & 0 \\
\hline Kaiapó do Mato Grosso & 0 & 0 & 0 & 0 & 0 \\
\hline Kaiapó do Pará & 3 & 33 & 30 & 0 & 1 \\
\hline Leste de Roraima & 10 & 64 & 44 & 17 & 3 \\
\hline Litoral Sul & 5 & 19 & 13 & 5 & 1 \\
\hline Manaus & 10 & 98 & 17 & 74 & 3 \\
\hline Maranhão & 82 & 116 & 112 & 1 & 1 \\
\hline Mato Grosso Do Sul & 10 & 76 & 44 & 32 & 0 \\
\hline Médio Rio Purus & 0 & 9 & 0 & 9 & 0 \\
\hline $\begin{array}{l}\text { Médio Rio Solimões and } \\
\text { Afluentes }\end{array}$ & 0 & 77 & 38 & 34 & 5 \\
\hline $\begin{array}{l}\text { Minas Gerais and Espírito } \\
\text { Santo }\end{array}$ & 28 & 3 & 0 & 3 & 0 \\
\hline Parintins & 0 & 30 & 9 & 19 & 2 \\
\hline Pernambuco & 2 & 40 & 13 & 21 & 2 \\
\hline Porto Velho & 25 & 12 & 8 & 3 & 1 \\
\hline Potiguara & 18 & 20 & 14 & 6 & 0 \\
\hline Rio Tapajós & 67 & 20 & 14 & 2 & 3 \\
\hline Tocantins & 0 & 0 & 0 & 0 & 0 \\
\hline Vale do Javari & 2 & 4 & 3 & 1 & 0 \\
\hline Vilhena & 0 & 0 & 0 & 0 & 0 \\
\hline Xavante & 0 & 4 & 3 & 0 & 1 \\
\hline Xingu & 2 & 0 & 0 & 0 & 0 \\
\hline Yanomami & 18 & 59 & 43 & 13 & 3 \\
\hline Total & 420 & 1737 & 934 & 715 & 70 \\
\hline
\end{tabular}

(iii) 6th April 2020 (date of the result's release): A 37-yearold Indigenous from the Kokama ethnicity tested positive for COVID-19 in the dSEI Alto Rio Solimões Amazonas, being one of the contacts of the Indigenous and Medical Doctor described on item II.

(iv) 9th April 2020: the first Indigenous death, being the one described on item (I).

(v) 9th April 2020: the second Indigenous death. The woman was admitted to the hospital due to her underlying conditions of autoimmune hemolytic anemia and systemic lupus erythematosus but has died due to acute respiratory failure caused by COVID-19. The patient's condition worsened after the acquisition of COVID-19, when she was put on ventilators.

(vi) 11th April 2020: the third Indigenous death, a 78 years old from Tikuna ethnic group in the dSEI Alto Rio Solimões - Amazonas. Patient had heart disease, admitted to the intensive care unit in Manaus, Amazonas. 
During the hospital treatment period, the test for COVID-19 was positive, which worsened the clinical outcome.

(vii) 17th April 2020: the fourth Indigenous death, being of 67 years old and Indigenous leader from Sateré-Mawé ethnic group - Amazonas, in the dSEI Parintins. He was hospitalized for presenting symptoms after the visit of his son who lives in Salvador (BA) and presented the cough symptom during the visit.

(viii) 24th April 2020: 30 new cases in the dSEI Alto Rio Solimões - Amazonas (due to contact with the doctor who returned from vacation on item II), and 13 in the dSEI Parintins - Amazonas (contacts of the first cases confirmed in dSEI Alto Rio Solimões - Amazonas).

(ix) 26th April 2020: the fifth Indigenous death that still need to be confirmed as COVID-19 positive, from Palikur ethnic group in the dSEI Amapá and Northern of Pará. The indigenous woman was 35 years old who died on April 3, 2020. Interestingly, the COVID-19 positive test confirmation was released on April 24, 2020. The causes of death were severe respiratory distress syndrome, bilateral lobar pneumonia, severe sepsis, right cervical abscess, and diabetes mellitus.

(x) 29th April 2020: the sixth Indigenous death from Tikuna ethnic group in the dSEI Alto Rio Solimões - Amazonas, with 63 years old. The patient presented the symptoms of fever, difficulties of breathing, and acute diarrhea.

(xi) 29th April 2020: the seventh Indigenous death from Tikuna ethnic group in the dSEI Alto Rio Solimões Amazonas. The 68 years old patient had diabetes mellitus and presented the symptoms of fever, headache, dry cough, and difficulty of breathing.

After these period of time corresponding to the first month after the first case of COVID-19 among Indigenous [9, 10], a total of 70 Indigenous deaths were described in 05 th June 2020. The deaths occurred mainly among older Indigenous or with comorbidities.

The Indians are the natural holders of the lands that make up the Brazilian territory. However, during the colonization, there was a drastic reduction of the Indigenous population. In the colonization period, Indigenous totalized $\sim 2$ millions of inhabitants. In the current context, there is $\sim 75 \%$ reduction in that number, in part due to the pandemic cycles that played a role. The indigenous people do not form a single social and cultural structure, but rather a socially and culturally diverse group, which can be evidenced by the number of languages among different ethnicities. The loss of indigenous ethnicities, in addition to characterizing the loss of life, reflects cultural and social loss that are irreparable.

It is possible to determine the route of SARS-CoV-2 in the presented Indigenous cases, mainly in the dSEI Alto Rio
Solimões - Amazonas. The first case had previous contact with a doctor who, in the latency phase, had access to an Indigenous group, and among them, an Indigenous woman was infected. When the indigenous woman returned to her ethnic group, she spreads the virus, and after $\sim 1$ month, numerous cases occurred among the members of her ethnic group.

Indigenous characteristics are important to describe and, among them, the fundamental role of older individuals. Senior individuals represent the knowledge and culture of the Indigenous population. However, some traditional culture habits have been mixed with modern society habits. COVID-19 is associated with a higher risk of death in older patients and comorbidities. Evaluating the Indigenous cases described here, the age ranged from 0 months to 88 years, being one of the oldest an Indigenous leader and an invaluable loss for their Indigenous ethnic group. Still, among the cases, many Indigenous presented comorbidities associated with a greater severity of COVID-19. The impact of COVID-19 pandemic on tribal chief (Cacique) or village Elder can lead to the extinction of their cultures, because the traditions are passed on orally by the elders [11].

At the time of the pandemic, it is important to minimize contact with Indigenous groups to limit the contagion, which is a crucial measure to be taken [8]. However, in addition to the Indigenous socialization outside their lands, especially in the Southeast region, they have contact with health professionals and other individuals as loggers, miners, and squatters, who often trespass on the Indigenous lands and have taken advantage of the COVID-19 pandemic to optimize their profiteering in areas previously preserved and destined to Indigenous people by law. Despite the social struggles to minimize the devastation of the forest and reduce the proliferation of infectious diseases [12,13], the current Brazilian political scenario did not create a protective environment and deforestation has increased exponentially [14]. As described by Ferrante and Fearnside (2020), the Indigenous community should be considered as a risk group, especially if considering the impact that other pandemics have had on this population, forcing the governmental actions as to highlight the isolation and protectionism position [15]. However, as described by the authors, the Brazilian authorities are trying to minimize the possibly catastrophic effect of COVID-19 pandemic for the Indigenous group. However, it is crucial to understand the effects of territorial invasions in the COVID-19 pandemic, mainly as a risk factor to promote the infection by SARSCoV-2 [16].

An important factor is to obtain the epidemiological data regarding ethnicity, such as Caucasoid or Negroid, and the application of the same data to understand the progression of the disease in communities such as Indigenous population [17]. 
Regardless of life quality on Indigenous territories as other regions, Brazil have low rates of access to drinking water and basic sanitation, both of which can optimize the progression of the COVID-19 virus. Another important fact is that in the Northern region, where there are the largest number of Indigenous population mainly in the state of Amazonas, $100 \%$ of the beds in the intensive care units were already occupied [11]. Thus, there was a health service collapse due to COVID-19 pandemic [11]. Besides, death numbers due to the respiratory illnesses exceeded the expected values for the time of the year compared with previous years. Finally, the limited access of Indigenous population to health services are often dependent on doctors and other health professionals visiting their lands.

Possibly, many Indigenous individuals who had contact with the first cases will die and will not be statistical counted due to the lack of knowledge about the disease and the possibility of its diagnosis. In the current scenario, it is difficult to have hope and believe that all Brazilians with COVID-19 will have the ideal medical support and recommended by the World Health Organization. Probably, many Brazilians have died and will die from COVID-19 without proper diagnosis and/or management. In the Indigenous population, the scenario can be even more tragic, since, unfortunately, it is a COVID-19 vulnerable and at-risk population. Historically, Indigenous population has been devalued and discriminated against by the Federal Government. Politics [18] and technical support [19], mainly associated with the diagnosis, should be better implemented in Brazil to provide support to all individual during the pandemic, mainly the more vulnerable to COVID-19.

In conclusion, our data reveal the importance of social isolation, especially for Indigenous population that were described as vulnerable and at-risk for COVID-19, highlighted by the identification of community infection. An individual of the Kokama ethnicity was infected after contact with a doctor with the disease, and both, the Indigenous and doctor, were responsible for transmitting the disease to other Indigenous in the Alto Rio Solimões and in Parintis, causing some of the confirmed deaths. The impact of COVID-19 may be an unprecedented tragedy for the Indigenous population, and the Brazilian government must take emergency measures to encounter the tragic outcomes of the disease.

Author Contributions All authors have approved the manuscript and agreed with its submission to the journal. Also, CVCP, MMO and FALM wrote and revised the manuscript.

\section{Compliance with Ethical Standards}

Conflict of Interest The authors declare that they have no conflict of interest.

\section{References}

1. https://www.worldometers.info/coronavirus/. Accessed at $03^{\text {rd }}$ May 2020.

2. https://www.who.int/emergencies/diseases/novel-coronavirus2019. Accessed at $03^{\text {rd }}$ May 2020.

3. La Ruche G, Tarantola A, Barboza P, Vaillant L, Gueguen J, Gastellu-Etchegorry M, et al. The 2009 pandemic H1N1 influenza and indigenous populations of the Americas and the Pacific. Euro Surveill. 2009;14(42).

4. Cardoso AM, Resende PC, Paixao ES, Tavares FG, Farias YN, Barreto CTG, et al. Investigation of an outbreak of acute respiratory disease in an indigenous village in Brazil: contribution of influenza A(H1N1)pdm09 and human respiratory syncytial viruses. PLoS One. 2019;14(7):e0218925. https://doi.org/10.1371/journal.pone. 0218925.

5. Lu R, Zhao X, Li J, Niu P, Yang B, Wu H, et al. Genomic characterisation and epidemiology of 2019 novel coronavirus: implications for virus origins and receptor binding. Lancet. 2020;395(10224):565-74. https://doi.org/10.1016/S01406736(20)30251-8.

6. Censo Demográfico. Características da população e dos domicílios: resultados do universo. Rio de Janeiro: IBGE; 2010. p. 2011.

7. FUNAI. Fundação Nacional do Índio. www.funai.gov.br. Accessed at $03^{\text {rd }}$ May 2020.

8. Amigo I. Indigenous communities in Brazil fear pandemic's impact. Science. 2020;368(6489):352. https://doi.org/10.1126/ science.368.6489.352.

9. Saúde Indígena. http://saudeindigena.net.br/dsei/. Accessed at $03^{\text {rd }}$ May 2020.

10. APIB. Articulation of the Indigenous Peoples of Brazil. http://apib. info. Accessed at $03^{\text {rd }}$ May 2020.

11. Ferrante L, Steinmetz WA, Almeida ACL, Leão J, Vassão RC, Tupinambás U, et al. Brazil's policies condemn Amazonia to a second wave of COVID-19. Nat Med. 2020;26(9):1315. https:// doi.org/10.1038/s41591-020-1026-x.

12. Ellwanger JH, Kulmann-Leal B, Kaminski VL, Valverde-Villegas JM, Veiga ABGD, Spilki FR, et al. Beyond diversity loss and climate change: impacts of Amazon deforestation on infectious diseases and public health. An Acad Bras Cienc. 2020;92(1): e20191375. https://doi.org/10.1590/0001-3765202020191375.

13. Carino G, Diniz D. Deforestation and Brazil's Indigenous population. Lancet. 2020;394(10216):2241. https://doi.org/10.1016/ S0140-6736(19)32620-0.

14. The Lancet. Bolsonaro threatens survival of Brazil's Indigenous population. Lancet. 2019;394(10197):444. https://doi.org/10.1016/ S0140-6736(19)31801-X.

15. Ferrante L, Fearnside PM. Protect Indigenous peoples from COVID-19. Science. 368(6488):251. https://doi.org/10.1126/ science.abc0073.

16. Ferrante L, Fearnside PM. Brazil threatens Indigenous lands. Science. 2020;368(6490):481-2. https://doi.org/10.1126/science. abb6327.

17. Zavaleta C. COVID-19: review indigenous peoples' data. Nature. 2020;580(7802):185. https://doi.org/10.1038/d41586-020-010321.

18. Marson FAL, Ortega MM. COVID-19 in Brazil. Pulmonology. 2020; in press;26:241-4.

19. Marson FAL. One million cases of COVID-19: what have we learned? Rev Med (São Paulo). 2020;99(2):209-12. https://doi. org/10.11606/issn.1679-9836.v99i2p209-212.

Publisher's Note Springer Nature remains neutral with regard to jurisdictional claims in published maps and institutional affiliations. 